\title{
Global Trends and Challenges for School Leaders: Keeping the Focus on Learning
}

\section{Peter Earley}

UCL Institute of Education - London - Department of Learning and Leadership (UK)

doi: 10.7358/ecps-2016-014-earl

p.earley@ucl.ac.uk

\section{LE TENDENZE GLOBALI E LE SFIDE PER DIRIGENTI SCOLASTICI: MANTENERE IL FOCUS SULLA FORMAZIONE}

\begin{abstract}
This paper gives consideration to global trends and recent developments in education systems, particularly as they relate to schools and school leaders operating in high stakes accountability cultures. The importance of leadership for organisation success is noted alongside a number of other key within-school factors such as teacher quality. Successful leaders are differentiated from high-performing leaders and the notion of "leadership for learning" is outlined. This leads to a discussion of the nature of learning-leading learning for what? - and the accountability pressures that make its enactment increasingly problematic whilst, in some cases, leading to undesirable practices. There is need for a cadre of proactive, reflective leadership professionals with social responsibilities. Education systems and schools need reflective professionals who are able to make judgements and act upon what is considered to be "educationally desirable». The challenges educational leaders face, both now and in the future, including keeping the focus on "learning" and seeing themselves as proactive reflexive leadership professionals, are also discussed.
\end{abstract}

Keywords: Accountability, High stakes testing, Leadership for learning, Learningcentred leadership, Successful leadership, Toxic leadership. 
"Instead of talking about pedagogy and education, it's all about exam tactics and preparation for inspection"

London secondary school headteacher (2016)

\section{INTRODUCTION}

The role of school leaders in Europe, North America and Australasia, has changed considerably over recent decades, in particular with regard to the levels and patterns of accountability, the nature of their responsibilities and the extent of institutional autonomy (Schleicher, 2012). This has been the case especially for headteachers or principals but has had effects for school leaders at all levels of the organisation. An interest in leadership has grown globally as there has been a growing recognition of its impact on the performance of educational systems. School leadership has changed over time to meet the ever-growing and changing demands of national policy-makers and other stakeholders (Earley, 2013), yet the constant factor over this period has been the need for schools continuously to raise standards and improve the quality of teaching and learning. The key to improving educational standards is increasingly seen in the growth of human capital - in particular, raising the quality of teachers and school leaders.

Cranston (2013, p. 131) has described this period as «an era of standards-based agendas, enhanced centralized accountability systems where improved student learning, narrowly defined, becomes the mantra for school leaders, who themselves are subject to enhanced accountabilities». He also said educational leaders «need to position themselves as proactive reflexive leadership professionals not reactive managers» (ibid., p. 139) responding to others' agendas and complying with external mandates i.e. proactive leadership professionals. It is a central theme of this paper to reinforce this message and to note why this «response» is not always forthcoming.

Throughout the world, education policy makers have continued the trend towards institutional autonomy and decentralisation, devolving decision-making and resources to schools in the belief that this will improve quality and encourage innovation. The British government's 2016 White Paper Education excellence everywhere (DfE, 2016) which aims for all statemaintained schools in England to become Academies (state-aimed autonomous schools) by 2022 exemplifies this policy trend. In order to incentivise these trends and enhance student outcomes, national education systems have put in place accountability measures that combine quasi-market pressures (such as parental choice of school along with funds following the student) with central control and regulation. In recent years the two drivers of school 
improvement - competition and collaboration - have existed alongside each other as national policy-makers have aimed for a balance between the two that it is believed will bring the greatest benefits to system reform. In England it has resulted in schools becoming more connected as "competition remains, but now co-exists with collaboration and the creation of formal alliances through federations and chains» (Matthews et al., 2011, p. 3). The term "co-opetition" has been coined to describe this co-existence but it is high stakes accountability and strong inspection regimes that appear to be increasingly common, and not only in England. Yet as noted:

Overly tight accountability systems can flatten the very freedom and autonomy that governments want to encourage; schools can narrow learning by teaching to the test; they can look up to second guess what they think the inspectorate wants to see (rather than at the evidence base); and they can game the system through "cream-skimming» or by massaging their exam performance through various subtle tricks. (Greany \& Earley, 2017, p. 4)

The developments towards self-management can be seen as part of a broader trend, one which the well-known Finnish educationist, Pasi Sahlberg, has coined the Great Education Reform Movement or GERM. This describes the process of global borrowing and system reform, which he argues, is occurring in so many education systems throughout the world, both developed and less-developed (Sahlberg, 2011). Although Sahlberg makes no specific reference to leadership, he refers to the growth of accountability in national systems along with other common themes such as competition, testing, standardization and choice; for him they are all part of the GERM. He suggests that for education systems to become high-performing, they need to move from «test-based accountability» to "trust-based responsibility" and to give priority to professional capital and its development. High-performing jurisdictions give teachers "agency, moral purpose and autonomy» and have accountability systems based on trust. For Sahlberg the way forward - the "Fourth Way» - relies for its success on collaboration, personalisation, trustbased responsibility, professional capital and equity.

It is a central theme of this paper that there is a danger that this state of affairs is increasingly likely without a greater effort to promote the "Fourth Way». Such trends associated with the GERM are unlikely to be stemmed without resistance from the education profession and in particular from school leaders. In view of the many challenges, they need to guard against the implicit pressure that such high stakes accountability systems can exert on them to narrow the curriculum and adopt instrumental improvement approaches - exemplified by the quote noted above from the blog of a London headteacher in 2016. 


\section{SUCCESSFUL SCHOOL LEADERSHIP MATTERS}

There are many research studies and reports stating that school leadership is a crucial factor in effective school performance. Empirical studies linking student outcomes to leadership, especially principal leadership, date back to at least the mid-2000s. Such studies however consistently point to the indirect effect that leaders have, working as they do, with and through people, especially teachers. Karen Seashore Louis has been involved in many impact studies and remarks that:

Although leaders affect a variety of educational outcomes, their impact on students is largely indirect and is relatively small compared to other factors. While formal leaders interact with pupils in many circumstances, the impact of schooling on students occurs largely through more sustained relationships that occur in classrooms and peer groups. (Seashore Louis, 2015, p. 1)

Croft too strikes a cautionary note when he refers to the «tendency to overstate the importance of leadership as a standalone factor in improving attainment, to the neglect of understanding of how it interacts with other key school factors" (2016, p. 3). He further notes that leadership's influence on outcomes is «mediated by a number of school-related factors that are more proximal to the student level, if not also influenced by ongoing and interactive contextual factors» (ibid., p. 6). The effect of leaders is largely indirect; what leaders do and say, and how they demonstrate leadership, does affect pupil learning outcomes, but it is largely through the actions of others, most obviously teachers, that the effects of school leadership are mediated. Nevertheless, school leadership influences student outcomes more than any other factors, bar socio-economic background and quality of teaching, and whilst it is challenging to quantify the exact effect size or the precise combination of factors that lead to impact, the research evidence does largely reinforce the argument that «leadership matters».

A useful distinction can be made between «successful» and "high performing» leaders to differentiate such leaders from «toxic» leaders (Greany \& Earley, 2017), a small but possibly growing group (Craig, 2017). Toxic leaders are those whose schools strive to achieve high academic test or exam scores at the expense of everything else, such as a broad and balanced curriculum, staff and student wellbeing or developing leadership capacity or a culture of collaboration. Successful leaders also want to secure the highest possible standards, but whereas the "toxic» leader may be doing this because they are worried about the consequences of failure or to boost their egos, the "successful» leader's actions are grounded in a deeper moral purpose (Hopkins et al., 2014). 
As noted elsewhere:

Successful leaders are focussed on helping every child, whatever their background, to enjoy learning and to reach their potential, because this is the best chance that a child will have for a fulfilling and productive life. They draw on data and evidence in assessing the school's performance and in tackling areas for improvement. They are transformational and learning-centred in their approach: able to shape a compelling vision and to enact it through a focus on constantly improving practice backed by strong organisational management. They are «good» with people and believe in the potential of any child or staff member to develop and grow, including through distributing leadership and high quality professional learning. They provide challenge as well as support. They are fascinated by the content and process of learning and the ways in which it can be enhanced, for staff and pupils. They are sensitive to the school's context and the wider context within which it operates. Also they adapt their leadership to reflect that context whilst also working to alter it, for example by working with other schools and parents. They are committed to the success of all students and all schools, and so think and act as system leaders. They remain resilient, curious, outward looking, optimistic, collaborative and committed to social justice, but they are also pragmatists: prepared to challenge policy where necessary, but to subvert it when necessary. (Greany \& Earley, 2017, pp. 4-5)

Perhaps the core reason why leadership matters in schools is because of the impact if can have on teachers and teaching. Teaching, especially the quality of the teacher and the teaching and learning environment, is seen as the most significant «within-school» factor to impact on student outcomes. For example, Hattie (2015, p. 2) concludes that the greatest influence on student progression is "having highly expert, inspired and passionate teachers and school leaders working together to maximise the effect of their teaching on all students in their care». Leadership - and headteacher leadership in particular - can create and influence improvement in the teaching and learning environment and the organisation of the school which, in turn, indirectly impacts on student outcomes. As noted above, this leadership is often referred to as learning-centred leadership or leadership for learning.

\section{LEADERSHIP FOR LEARNING}

Bush and Glover (2014) helpfully divide models of leadership into six types: instructional leadership; managerial; transformational; moral and authentic; distributed; teacher leadership; system leadership; and contingent leadership. It is the first model, that of instructional or pedagogic leadership, that

\footnotetext{
ECPS Journal - 14/2016

http://www.ledonline.it/ECPS-Journal/
} 
has developed into leadership for learning or learning-centred leadership. In broad terms, whatever its label, it is an approach to leadership «whereby the leader helps foster a learning climate free of disruption, a system of clear teaching objectives, and high teacher expectations for students. Elements include principal leadership, clear mission, teaching expectations and opportunities to learn" (Osborne-Lampkin et al., 2015, cited in Earley, 2017, p. 103). Learning-centred leadership emphasises the centrality of teaching and learning and suggest that leaders' influence on student outcomes is via staff, especially teachers. Such leaders see leading learning as their main responsibility and one which takes priority over other aspects of their role.

For the OECD, leadership for learning is concerned to focus on supporting, evaluating and developing teacher quality which includes "coordinating the curriculum and teaching program, monitoring and evaluating teaching practice, promoting teachers professional development, and supporting collaborative work cultures» (Schleicher, 2012, p. 18). The OECD draws upon 2009 PISA data to consider school principals' views on their involvement in school matters across 34 member countries. Extracts from the OECD dataset are shown in Figure 1, and are indicate of how education systems and their leaders attend to various matters and how «learning atmospheres» may differ between schools and education systems. The ten activities listed in the figure might broadly be defined as constituting «learning-centred leadership» as each one is concerned with an aspect of teaching and learning. Among member countries, for example, $61 \%$ of students attend schools whose leaders «quite often» or "very often» take exam results into account when making decisions regarding curriculum development. This figure is much higher for both the UK (97\%) and Italy (77\%). Two-thirds of students attend schools whose leaders «quite often» or «very often» monitor students' work, which is much lower in both UK and Italy (87-88\%). Across the OECD member countries $29 \%$ attend schools whose leaders «quite often» or «very often» take over lessons from teachers who are unexpectedly absent, exactly the same percentage as in the UK but lower in Italy (18\%). Clear differences can be seen in the enactment of the headteacher role between the education systems of Italy and the UK. Perhaps the most striking example of differences concerned principal involvement in classroom observation; Italy's percentage (39\%) was lower than the OECD average $(50 \%)$ but principals' involvement in classroom observation was much higher in the UK (93\%), a figure only surpassed by the USA (95\%) among the 34 member countries. Interestingly OECD data also show the differences in member countries' inter- and intra-school variability, with the UK having much narrower between-school variability in school performance than Italy but much greater within-school variation. 


\begin{tabular}{|c|c|c|c|}
\hline School leaders ...(OECD 2012) & OECD & Italy & UK \\
\hline $\begin{array}{l}\text { Ensure that teachers' professional } \\
\text { development links to school goals }\end{array}$ & $88 \%$ & $97 \%$ & $100 \%$ \\
\hline Observe lessons & $50 \%$ & $39 \%$ & $93 \%$ \\
\hline $\begin{array}{l}\text { Suggest how teachers can } \\
\text { improve }\end{array}$ & $69 \%$ & $75 \%$ & $92 \%$ \\
\hline $\begin{array}{l}\text { Inform teachers about } \\
\text { possibilities for improving skills \& } \\
\text { knowledge }\end{array}$ & $89 \%$ & $98 \%$ & $96 \%$ \\
\hline Teach when teachers are absent & $29 \%$ & $18 \%$ & $29 \%$ \\
\hline School leaders ... (OECD 2012) & OECD & Italy & UK \\
\hline $\begin{array}{l}\text { Use student results to develop } \\
\text { school's goals }\end{array}$ & $75 \%$ & $86 \%$ & $100 \%$ \\
\hline Monitor students' work & $66 \%$ & $87 \%$ & $88 \%$ \\
\hline $\begin{array}{l}\text { When teachers have problems } \\
\text { take initiative to discuss matters }\end{array}$ & $86 \%$ & $96 \%$ & $90 \%$ \\
\hline $\begin{array}{l}\text { Check that classroom activities are } \\
\text { in keeping with educational goals }\end{array}$ & $72 \%$ & $88 \%$ & $95 \%$ \\
\hline $\begin{array}{l}\text { Take exam results into account in } \\
\text { decisions about curriculum } \\
\text { development }\end{array}$ & $61 \%$ & $77 \%$ & $97 \%$ \\
\hline
\end{tabular}

Figure 1. - Heads' views on involvement in school matters (adapted from Schleicher, 2012, p. 17).

\section{LEARNING FOR WHAT?}

The increasing emphasis on learning-centred leadership and the move globally towards leadership for learning has led a growing number of commentators to question or problematise the notion of «learning». For example, Smythe and Wrigley (2013) have argued that in the discourse of the new leadership, «even the term 'leading learning' has been reduced into monitoring attainment; the complexities of social justice are viewed very narrowly through the lens of reducing attainment gaps» (ibid., p. 156). For others, the global testing culture permeates all aspects of education, «from financing, to 
parental involvement, to teacher and student beliefs and practices» which has led «to an environment where testing becomes synonymous with accountability, which becomes synonymous with education quality» (Smith, 2016, p. 1). This narrow focus on exam results, test scores and league tables means students are increasingly leaving schooling without the skillset needed to survive, sometimes referred to as 21 st century skills. A cartoon encapsulates this scenario well when a prospective job candidate is asked "I see you did well in school, but what real-world skills do you have?» and replies «Tests, I can take tests!».

Operating in high stakes accountability systems where school leaders' positions may be highly dependent on the success of their last set of results and inspection outcomes is affecting education systems in a number of unexpected, unintended and unhelpful ways. For some the education system is being corrupted (ref to flip?). Reference was earlier made to ways in which schools may "game» the system and dubious behaviours among teachers seeking the best results is relatively widespread (e.g. see Ofqual, 2015). Regular reports are made of teachers "gaming" the system because they are under great pressure to achieve high test scores. As Hutchings notes in some English schools they are being instructed to cheat by their principals; indeed a growing number have been disbarred from practicing because of unethical and illegal behaviours. Such practices are «increasing in response to the intense pressure on school leaders and teachers to raise attainment as measured by tests and exams» $(2015$, p. 37). She adds that the high stakes accountability culture is leading to some schools becoming "exam factories» and pupils' emotional health and wellbeing is suffering because of «high-stakes testing» (ibid., p. 5).

The nature of "learning» - learning for what? - and its "leadership» leadership for what? - are therefore key questions for the future. How will leaders ensure that their focus on learning avoids schools becoming "examination factories» or «attainment hothouses» with a narrowly defined standardsbased curriculum, where teaching is to the test and other unsavoury and unethical practices are commonplace? Education systems should aim to assess what matters and quality should be judged not by performance on a small number of tests but geared towards the growth of individuals and the development of both cognitive and non-cognitive skills. Interestingly, high test scores are not a good predictor of future success of students or nations and effective teachers, defined in terms of securing high test scores, may in fact be creating negative attitudes towards the subject and to learning more broadly. A strong focus on attainment or the cognitive can cause damage and impact negatively on emotional health, stress and wellbeing of both students and teachers.

Robin Alexander speaks for many educationists when he said schools should provide: 
[...] a rich, fulfilling and empowering education which secures children's basic skills while raising their sights to larger educational horizons. To achieve this, we need to move from a concept of standards as test scores in limited aspects of literacy and numeracy to one that relates to the quality of provision and achievement across the entire curriculum to which children are entitled. (Alexander, 2011, p. 280)

Leadership for learning must be leadership with a purpose - it must be about learning that is more than just attainment, exam and test scores and meeting central government's policy objectives. Of course attainment is important as children's life chances have little chance of being realised without knowledge of the basics, but education - and learning - must be about more than this. Starratt (2007) argued that practitioners and researchers alike must always ask themselves the question "Leadership of and for what?" and without a clear answer to this then all the theory and research and discourse about leadership, including learning-centred leadership, "will not make what goes on in schools right» (ibid., p. 182).

\section{THE FUTURE?}

More and more educational systems are moving towards decentralization, schools are more autonomous in their decision-making, and increasingly held to account for their results which are made public and widely available. As schools have gained more autonomy, the more important the role of school leaders, especially principals and headteachers, has become. Leading the learning will need to take priority over other competing pressures but this may be easier said than done.

In England the nature and demands of education policy have been perceived as potentially disrupting the focus of schools from teaching and learning and their improvement (Earley, 2013). Additional managerial responsibilities and powers due to greater autonomy and structural changes could disrupt a leadership focus on learning. Leadership of learning will increasingly need to be seen as everybody's responsibility with school leaders fostering a culture of learning for all. School leaders will increasingly be extolled to become leaders of learning, with headteachers appraised or evaluated in terms of "fostering pedagogical leadership in schools» (OECD, 2013, p. 485). There will be a continuing expectation that school leaders focus their efforts on «learning matters» but it has been argued that these must be interpreted more broadly than is currently the case in some schools.

For Cranston, the rhetoric of self-management and devolution - and we might wish to add the discourse of leadership for learning - «has not resulted 
in schools and school leaders [...] determining and driving educational priorities». Many school leaders he argues have become the "doers» of the bidding of others rather than "playing a lead role in shaping school leadership professionalism and education more broadly for the 21 st century». In a similar vein, Andy Hargreaves argues that school autonomy is not always a good thing and can work against notions of learning-centred leadership as it tends to lead to "principals turning into de-professionalised performance managers and evaluators of teachers as individuals rather than builders of professional communities amongst all their staff within and across schools» (2016, p. 123).

National educational policies relating to decentralisation and school autonomy have given considerable powers to school leaders who, as noted elsewhere, now:

[...] sit at the fulcrum of high autonomy-high accountability systems and are expected to resolve the policy paradoxes of both competition and co-operation [...] they should: exercise their autonomy to innovate in response to parental needs, whilst at the same time meeting centrally prescribed targets and requirements; improve literacy and numeracy scores every year, while maintaining a broad and balanced curriculum; close attainment gaps, while pushing the brightest and the best; and collaborate with their peers to develop skills and capacity, while competing to ensure that (their schools) move up the local hierarchy. (Greany \& Earley, 2017, p. 4)

The challenge is how can leaders lead in autonomous and accountable systems in ways which recognise and resolve, or at least mitigate, the many tensions that they face. How will school leaders maintain their focus and efforts on professional and pedagogic matters (the learning) rather than administrative and financial concerns whilst also ensuring that focusing on learning includes wider or whole school discussion, about «learning for what?» (see Earley \& Greany, 2017). Efforts will need to be focused on how to create an education system whose success is not just assessed by test scores or exam results, but by how it is helping to develop students' character, resilience and well-being. The irony of course is that the two are complementary, they feed off each other.

School leaders continue to face many challenges and these challenges are unlikely to go away. There is a need for optimism and that the job of school leaders is seen as do-able. Much will depend on how school leaders choose to express their agency in responding to national policies and agendas. Greany (2015) has argued they they need to be proactive, not reactive, fatalist and fearful, be outward facing, act collectively, build capacity with shared values and moral purpose, not compliance focused or concentrating their efforts trying to meet the expectations of inspectors. Research in England suggests that headteachers fall into one of four categories in their response to 
the changing policy environment in which they operate: confident, cautious, concerned, or constrained (Higham \& Earley, 2013).

It is also important that «successful» leadership is not seen as finite and that leadership agency can be shaped and grown. School leadership, especially headship has often been seen as «a work of passion» and most of those working in education do so with a moral purpose. The following quote from an English secondary school head about working in a high stakes and high accountability culture provides optimism for the future. He said:

I expected to feel the weight of this on my shoulders when I accepted the job as a head - however what I didn't expect to outweigh this was the huge social responsibility entrusted to heads to create an environment in schools that enables students to use their education to improve their life chances. This, unquestionably for me, is the one aspect of the job that provides me with my greatest motivation and my greatest challenge and it is something I will continue to relish throughout my career. (SecEd, July 2, 2015, p. 8)

There is need for a cadre of proactive, reflective leadership professionals with social responsibilities.

Education systems and schools need reflective professionals who are able to make judgements and act upon what is considered to be «educationally desirable». Leadership for learning must be leadership with a purpose; it is argued here that it must be about learning in the broadest sense. The challenges are numerous and wide-ranging and school leaders will continue to operate in a volatile, uncertain, complex and ambiguous environment. They will need considerable support and on-going development if their increasingly autonomous schools are to provide the kind of education needed to live and work in the twenty-first century.

\section{REFERENCES}

Alexander, R. (2011). Evidence, rhetoric and collateral damage: The problematic pursuit of "world class» standards. Cambridge Journal of Education, 41(3), 265-286.

Bush, T., \& Glover, D. (2014). School leadership models: What do we know? School Leadership and Management, 34(5), 553-571.

Craig, I. (2017). Toxic leadership. In P. Earley \& T. Greany (Eds.), School leadership and education system reform (pp. 182-190). London: Bloomsbury.

Cranston, N. (2013). School leaders leading: Professional responsibility not accountability as the key focus. Educational Management, Administration \& Leadership, 41(2), 129-142. 
Croft, J. (2016). Taking a lead: How to access the leadership premium. Research report nr. 9. London: Centre for the Study of Market Reform of Education.

DfE - Department for Education (2016). Education excellence everywhere. London: DfE.

Earley, P. (2013). Exploring the school leadership landscape: Changing demands, changing realities. London: Bloomsbury.

Earley, P. (2017). Conceptions of leadership and leading the learning. In P. Earley \& T. Greany (Eds.), School leadership and education system reform (pp. 100-110). London: Bloomsbury.

Earley, P., \& Greany, T. (Eds.). (2017). School leadership and education system reform. London: Bloomsbury.

Greany, T. (2015). More fragmented, and yet more networked: Analysing the responses of two local authorities in England to the coalition's «self-improving school-led system» reforms. London Review of Education, 13(2), 125-143.

Greany, T., \& Earley, P. (2017). Introduction. In P. Earley \& T. Greany (Eds.), School leadership and education system reform. London: Bloomsbury.

Hargreaves, A. (2016). Autonomy and transparency: Two good ideas gone bad. In J. Evers \& R. Kneyber (Eds.), Flip the system: Changing education from the ground up (pp. 120-133). London: Routledge.

Hattie, J. (2015). The politics of collective expertise. London: Pearson.

Higham, R., \& Earley, P. (2013). School autonomy and central control in England: School leaders' views on a changing policy landscape. Educational Management, Administration and Leadership, 41(6), 701-717.

Hopkins, D., Stringfield, S., Harris, A., Stoll, L., \& Mackay, T. (2014). School and system improvement: A state of the art review. School Effectiveness and School Improvement, 25(2), 257-281.

Hutchings, M. (2015). Exam factories? The impact of accountability measures on children and young people. London: NUT.

Matthews, P., Higham, R., Stoll, L., Brennan, J., \& Riley, K. (2011). Prepared to lead: How schools, federations and chains grow education leaders. Nottingham: National College for School Leadership.

OECD (2013). Synergies for better learning: An international perspective on evaluation and assessment. Paris: OECD.

Ofqual - Office for Qualifications (2015). Annual report, July. London: Ofqual.

Osborne-Lampkin, L., Folsom, J. S., \& Herrington, C. D. (2015). A systematic review of the relationships between principal characteristics and student achievement (REL 2016-091). Washington, DC: U.S. Department of Education, Institute of Education Sciences, National Center for Education Evaluation and Regional Assistance, Regional Educational Laboratory Southeast.

Sahlberg, P. (2011). Finnish lessons. New York: Teachers College Press. 
Schleicher, A. (Ed.). (2012). Preparing teachers and developing school leaders for the 21st century: Lessons from around the world. Paris: OECD.

Seashore Louis, K. (2015). Linking leadership to learning: State, district and local effects. Nordic Journal of Studies in Educational Policy, 1, 30321. http:// dx.doi.org/10.3402/nstep.v1.30321

Smith, W. C. (Ed.). (2016). The global testing culture: Shaping education policy, perceptions, and practice. Oxford: Symposium Books.

Smythe, J., \& Wrigley, T. (2013). Living on the edge: Rethinking poverty, class and schooling. New York: Peter Lang.

Starratt, R. J. (2007). Leading a community of learners: Learning to be moral by engaging the morality of learning. Educational Management, Administration and Leadership, 35(2), 165-183.

\section{Riassunto}

Questo articolo prende in considerazione le tendenze globali e gli sviluppi recenti dei sistemi di istruzione, in particolare per quanto concerne le scuole e i dirigenti scolastici che operano in culture che richiedono alte responsabilità. L'importanza della leadership orientata al successo dell'organizzazione è rilevata accanto ad una serie di altri importanti fattori che riguardano la scuola dal di dentro come la qualità degli insegnanti. Si precisa come i leader orientati al successo si differenziano dai leader centrati su alte prestazioni e viene delineato il concetto di "guida per l'apprendimento". Ciò apre una discussione sulla natura del sapereleader orientati all'apprendimento, per apprendere che cosa? - e sulle pressioni e le responsabilità che rendono l'attuazione della leadership sempre più problematica e, in alcuni casi, portano a pratiche indesiderate. C'è bisogno di una squadra di professionisti, di leadership proattive che si prendano responsabilità sociali. I sistemi di istruzione e le scuole hanno bisogno di professionisti responsabili che siano in grado di esprimere giudizi e agire verso ciò che è ritenuto essere "desiderabile a livello educativo". Si argomenta inoltre sulla sfida del leader educativo che riguarda, sia ora che in futuro, la capacità di mantenere il focus sull'«apprendimento" e vedere se stessi come professionisti proattivi di leadership riflessiva.

Parole chiave: Apprendimento centrato sulla leadership, Leadership orientate al successo, Leadership per l'apprendimento, Leadership tossica, Responsabilità.

How to cite this Paper: Earley, P. (2016). Global trends and challenges for school leaders: Keeping the focus on learning [Le tendenze globali e le sfide per dirigenti scolastici: mantenere il focus sulla formazione]. Journal of Educational, Cultural and Psychological Studies, 14, 21-33. doi: 10.7358/ecps-2016-014-earl 